\title{
Demographic pressure in Serra do Mar State Park and its buffer zone, southeastern Brazil
}

\author{
Roberto Starzynski • Silvio Jorge Coelho Simões • \\ Paulo Valladares Soares • Tatiana Sussel Gonçalves Mendes
}

Received: 7 November 2017 / Accepted: 2 August 2018 / Published online: 10 August 2018

(C) Springer Nature Switzerland AG 2018

\begin{abstract}
The Serra do Mar State Park forms a green corridor that connects significant remnants of the Atlantic Forest in Brazil, a region that presents great biodiversity. However, the mounting pressure exerted on it by disorderly urban expansion around conservation unit areas is a cause for concern. Thereby, this paper aims to analyze a geographical and demographic characterization of Serra do Mar State Park and its buffer zone in order to identify regions under the greatest pressure and provide subsidies for developing public policies. The study is based on a
\end{abstract}

R. Starzynski $(\bowtie)$

Department of State Parks and Reserves, Forest Institute, Rua do Horto, 931, Horto Florestal, São Paulo, SP 02377-000, Brazil e-mail: rostarzynski@hotmail.com

S. J. C. Simões • T. S. G. Mendes

Environmental Engineering Department, São Paulo State University (Unesp), Institute of Science and Technology, Rodovia Presidente Dutra, km 137,8, São José dos Campos,

SP 12247-004, Brazil

S. J. C. Simões

e-mail: silvio.jorge.simoes@gmail.com

T. S. G. Mendes

e-mail: tatiana.mendes@ict.unesp.br

P. V. Soares

School of Engineering of Guaratinguetá, Department of Civil Engineering, São Paulo State University (Unesp), Avenida Ariberto Pereira da Cunha, 333. Portal das Colinas, 12, Guaratinguetá, SP 516-410, Brazil

e-mail: paulo.valladares27@gmail.com cartographic representation using a geographic information system associated with the 2010 Census demographic data, which has been conducted by the Brazilian Institute of Geography and Statistics (IBGE in Portuguese acronym). The study area covers the territory of 32 municipalities and it was found that almost 25,000 inhabitants live inside the park while approximately 712,000 residents live inside its buffer zone.

Keywords Conservation unit · Buffer zone · Demographic pressure $\cdot$ Geospatial analysis

\section{Introduction}

Due to intense processes of landscape transformation and subsequent degradation that has been occurring over the last century, actions aimed at preserving biotic and abiotic resources have become increasingly necessary and urgent nowadays. On the other hand, an enormous urban expansion and the increasing demand for natural resources impose socioeconomic barriers that challenge the conciliation of production systems with conservationist actions, which is mainly due to a lack of basic research and effective public politics. The creation of areas of integral protection conservation in Brazil presents distinctions when compared with those adopted by other countries. While in the USA, for example, national parks were set up in regions not yet occupied by colonizers, in Brazil many units were established in places where population concentrations already existed, because the purpose was to protect environmentally 
important areas from immediate impacts and future pressures (Castro Júnior et al. 2009). Thus, several environmental conservation units (CUs) face a conflicting relationship with human occupation, both in its interior and in its surroundings, which compromises the preservation of their natural resources and biodiversity protection, as well as interfering in the quality of life of residents. These conflicts may pose a threat to the stability of protected areas and cause a movement to reduce them through the downgrading, downsizing, degazettement, or reclassification (Bernard et al. 2014; De Marques and Peres 2015).

Managing protected areas involves greater complexity when considering the need to create areas that buffer the surrounding pressures. In order for CUs to fulfill their role, they cannot be operated as islands, due to requiring actions on larger scales, such as the creation of buffer zones to be used as barriers. This prevents external anthropogenic activities that could endanger natural ecosystems within protected areas through habitat fragmentation and loss, introduction of exotic species and diseases, as well as contaminating the soil, water, and atmosphere (Vitalli et al. 2009). The concept of special zones around protected areas was introduced in 1971 through a program called "The Man and the Biosphere Programme - MaB" (UNESCO 1971) which created biosphere reserves composed of a nucleus zone, formed by protected areas, and a buffer zone (BZ) where social, cultural, and environmental sustainable economic and human development activities can be authorized.

The first legal decree that established a special protection zone around CUs in Brazil was the Resolution 13/90 (Brasil 1990) created by the National Environment Council (CONAMA), which makes use of the term "Surrounding zone" to define the region located within a radius of $10 \mathrm{~km}$ around CUs. In Brazil, the term "Zona Tampão" is also used to designate the region around a CU, while the term "Buffer Zone" is used internationally. Law 9.985/2000 (Brasil 2000) established the need for a BZ, defined as the surroundings of a $\mathrm{CU}$, where human activities are subject to specific norms and restrictions in order to minimize negative impacts on it; its extent, location, and restrictions should be defined once a management plan is drawn up. The Sao Paulo State has established the Decree 60302/14 (São Paulo 2014), which instituted the São Paulo State Management System of Protected Areas and Areas of Environmental Interest (SIGAP). This decree determines that areas comprising the BZ of a CU should be considered as a priority in the formulation of public policies of economic incentives for preserving the surrounding zone. It also establishes a payment process for environmental services, both within the CU and its BZ, as well as in green corridors.

Vitalli et al. (2009) have analyzed the importance of surrounding zones for CUs and found that their existence could only be effective if it were supported by specific legislation, since such lands are commonly owned by third parties, in which there is an administrative limitation that imposes restrictions on exercising the right of ownership, aiming at protecting natural resources. BZ extension is an important issue to be settled. Li et al. (1999) considered it simple to establish a fixed width around the protected area and suggested that its delimitation should be done in different sectors with different widths defined by ecological, social, and economic factors. The authors conducted a case study aiming to establish the BZ of the Yancheng Biosphere Reserve in China by using a method that combines quantitative and qualitative approaches.

Zoning of protected areas requires assessment of their several attributes according to multiple objectives. To promote transparency and facilitate communication with interested parties, a clear, detailed, and scientifically based methodology needs to be adopted (Geneletti and Duren 2008). A quantitative method to form zones of protected areas and to assess their ecological implications was developed by Sabatini et al. (2007); these authors suggested an innovative methodology regarding the application of the quadratic distance between units of area, non-reciprocal weights for using nonadjacent lands, and the possibility of imposing connectivity restrictions. They considered that a quantitative method should not be a definite response to buffer zones around protected areas, but it is a quick and inexpensive tool that can provide starting points for participatory zoning to be undertaken by technicians and stakeholders involved. Zhang et al. (2013) applied, for the Meili Snow Mountain National Park in China, a methodology that uses geographic information system (GIS) techniques associated with a participatory process in which technicians and various social actors have identified and pondered criteria and impact factors for each action to be developed in the park, such as nature conservation, tourism/ recreation, and community development.

The relationship between people and protected areas has been researched both on conservation ecology and anthropology communities. Certain segments of the 
conservation community claim that protected areas can encourage immigration towards their outskirts, thus accelerating their isolation from natural landscapes. On the other hand, in anthropological segments, it is argued that protected areas can deter neighboring human communities and disrupt traditional rural development methods (Joppa 2011-2012). This dichotomy can be observed in various works published about this issue. Wittemyer et al. (2008) analyzed the demographics of protected environmental areas in Africa and Latin America by finding a significant population increase within a 10 $\mathrm{km}$ area around them if compared to areas that do not belong to parks. They suggest that this pattern stems from people's expectation of enjoying the social, economic, and infrastructure benefits that parks can provide, which could pose a threat to biodiversity around the conservation units.

Similarly, Mmom and Mbee (2013), studying the depletion of natural resources in the Gele-Gele Forest Reserve in Nigeria, found that there is a rapid decline in forest resources and biodiversity, which is caused by the growth of communities living around its area. The results also showed that when local population are not engaged in conservation efforts, the degradation process increases; however, when these local populations see themselves as actors in the conservation of protected areas, they contribute with a certain amount of effort to protect the environment. In Africa, population growth in the vicinity of CU was also studied by Bamford et al. (2014) in a wildlife management area in Tanzania. The authors found an annual growth of 5\%, where the increase of the population does not seem to be related to the protected area because few residents know the wildlife management plan and few receive benefits from the wildlife and, therefore, had little reason to keep it.

Harvey et al. (2008) studied biodiversity conservation in Central America and have suggested that a reconciliation between existing efforts in protected areas and environmentally sustainable agriculture in their surrounding zones would be interesting, both for the conservation and livelihood of rural communities. However, Schimandeiro et al. (2008) investigated the characteristics of agricultural systems used for cultivating corn and soybean in the surrounding zone of a State Park situated in Vila Velha, southern Brazil, a region where most farms pose a threat to local ecosystems preservation, and suggested that management alternatives for reducing the environmental impact of agricultural production could arise from experiments developed with producers by using cutting-edge technology and specialized technical support from research agencies.

The effectiveness of BZs that are already established, as well as the concern for preserving their biodiversity, has been the object of study of several researchers. Authors, such as Moraes et al. (2015), Nora et al. (2009), Lima et al. (2013), Moraes et al. (2017), and Almeida et al. (2018), verified the low effectiveness of BZs in some Brazilian CUs. Costa et al. (2011) verified that most of Brazilian CUs face serious problems such as land issues, deforestation, and burnings, as well as a lack of personnel and infrastructure. The situation of urban CUs is much more serious when located in the middle of dense human occupation, where there are no governmental actions that control population growth in their surroundings. By suggesting a delimitation of the Pedra Branca State Park's BZ, located in the city of Rio de Janeiro, the authors mention population density as one of the main parameters to be analyzed, since densely populated areas should remain outside of the BZ boundary. Freitas Lima and Ranieri (2018) studied the relationship between the surrounding region of CUs that protect the Atlantic Forest in southeastern Brazil and concluded that the effectiveness of the BZs depends on a good relationship with the local municipal governments responsible for the elaboration of the municipal master plans. Otherwise, the establishment of the BZs risks being only a symbolic action, with no practical effect on biodiversity conservation within the protected area.

Studies focusing on demographic pressure around CUs can be carried out with a focus on one or more protected areas. There is a tendency for the study involving several CUs, such as those on a global scale conducted by Wittemyer et al. (2008). However, such large-scale analyses are inherently incapable of providing a realistic depiction of human population trends around protected areas (Hoffman et al. 2011). Global population data analysis is hindered by a variety of data collection procedures and interpolations of results obtained in different countries with specific situations. Any analysis performed by this method will inevitably compare significantly different data, which may lead to errors in conclusions.

Therefore, an analysis based on individual case studies of protected areas (Joppa 2011-2012) is recommended. Following in this direction, this work focuses on the geographic and demographic analysis of a single $\mathrm{CU}$, the largest protected area of the Atlantic rain forest. 
Thus, the main contribution herein is to present a geographic and demographic characterization of Serra do Mar State Park (SMSP) and its BZ with the aim of identifying the regions under the greatest pressure and providing subsidies for developing public policies.

\section{Serra do Mar State Park}

The SMSP was created in 1977 with the aim of ensuring an effective protection of flora, fauna, and natural landmarks, as well as being used for educational, recreational, and scientific purposes (São Paulo 1977). It is located in eastern São Paulo State along the Serra do Mar and forms a green corridor that connects significant remnants of the Atlantic Forest in Brazil which is currently quite fragmented. According to Ribeiro et al. (2009), the Atlantic Forest is currently distributed in 245,173 forest fragments with more than $80 \%$ of them being smaller than $50 \mathrm{ha}\left(0.5 \mathrm{~km}^{2}\right)$ and have an average separation of $1.44 \mathrm{~km}$. In this framework, the SMSP is the largest CU of this biome and contains the largest continuous portion of the ecosystem.

It has an enormous biological diversity with a huge variety of plants, mammals, birds, fish, insects, reptiles, trees, fungi, and bacteria. While elaborating its management plan (São Paulo 2006a), 1265 species of vascular plants had been found in different configurations of the Atlantic Forest and were identified based on the altitude variation between the high mountain range and the coast. The main units are described below: (1) Altitude fields occur at altitudes up to $1500 \mathrm{~m}$ being characterized by vegetation of grasses and small shrubs associated with shallow, poorly developed soils, and (2) Hillside forests occur in the mountain slopes formed mainly by clayey soils. These environmental conditions allow for the development of a dense and exuberant forest, with a canopy height of 25 to $30 \mathrm{~m}$; (3) Coastal plain forests are situated below $300 \mathrm{~m}$ and are constituted by fluvial and lacustrine deposition associated with limiting factors, such as high salinity, low nutrient supply, and soil instability; (4) Restinga areas are located between the hillside forest and the ocean and grow in dune regions with vegetation formed by near-shrub or shrub aspects; and (5) mangroves which are found in the rivers mouths associated with muddy, unstable, and high salinity soils due to tidal fluctuations.

As regards its fauna, 111 species of mammals, 373 of birds, 144 of amphibians, and 46 species of reptiles have been found. In addition to biodiversity protection, it provides significant ecosystem services, especially in urban centers located in its surroundings, thus demonstrating several positive aspects such as reduction of temperatures, providing better protection to residents of hazardous areas, and regulating the flow of springs, thus ensuring a quantitative and qualitative water supply (Starzynski 2014). The preservation of the park is also important for public health, since the risk of infection of diseases, such as Brazilian spotted fever is correlated to the deforestation and the lack of connection among the remaining patches of Atlantic rain forest (Scinachi et al. 2017).

According to the Law 9.985/2000 (Brasil 2000) which established the National System of Environmental Conservation Units (SNUC - Sistema Nacional de Unidades de Conservação), SMSP is a member of a group called "Full Protection Conservation Units," whose essential aim is to preserve the environment, in which only an indirect use of natural resources is permitted; its area must be for the purposes of public domain, and private properties within its boundaries must be expropriated, its residents compensated and thus relocated outside the CU.

The management plan mentioned before (São Paulo 2006a) has been approved by the Environmental State Council (São Paulo 2006b) and constitutes the main instrument for planning and evaluating performed actions. A technical team is responsible for surveys and analysis of the natural ecosystem and cultural heritage, as well as to protect the park from pressures and threats posed by human occupation and public use. Knowledge generated by the technical team has stimulated discussions with local communities and the stakeholders about the concepts of participatory planning and management, which allowed the local population to approve the management plan and recommended actions. Although the SMSP management plan (São Paulo 2006a, b) has evaluated areas of each municipality within the park, a demographic characterization of its BZ has not been conducted so far, but only zoning criteria and a brief description were included in it.

\section{Geographic position}

The SMSP territory comprises 22 municipalities, of which 12 are in the coastal region (Ubatuba, Caraguatatuba, São Sebastião, Bertioga, Cubatão, Santos, São Vicente, Praia Grande, Mongaguá, Itanhaém, Peruíbe, and Pedro de Toledo) and 11 are in the plateau 
region (Cunha, São Luiz do Paraitinga, Natividade da Serra, Paraibuna, Salesópolis, Biritiba Mirim, Mogi das Cruzes, Santo André, São Bernardo do Campo, São Paulo, and Juquitiba). Starzynski (2014) studied the SMSP georeferenced data, found that its area is $3037.8 \mathrm{~km}^{2}$, and observed that nine municipalities have over $30 \%$ of their geographical territory inside the SMSP, five of which are São Vicente, Cubatão, Santos, Itanhaém, and Praia Grande, whose territorial percentages approximately range between 30 and $45 \%$, while four municipalities - Ubatuba, São Sebastião, Caraguatatuba, and Pedro de Toledo - have approximately 60 to $70 \%$ of their geographical territory within the CU. The BZ, has an area of $4980 \mathrm{~km}^{2}$ and it comprises the following municipalities: Embu-Guaçu, Guarujá, Itariri, Miracatu, Ribeirão Pires, Rio Grande da Serra, São Lourenço da Serra, and Suzano, all of them in the São Paulo state, and Parati in Rio de Janeiro state.

The area of each municipality located inside the SMSP and BZ has been calculated for the study region using geoprocessing techniques. Twenty-one municipalities have over $30 \%$ of their geographical territory located in the BZ, nine of which-Rio Grande da Serra, Itariri, Mongaguá, Cubatão, Juquitiba, Itanhaém, Biritiba Mirim, Santo André, and Salesópolis-have over $50 \%$ of their geographical territory situated within the SMSP. The most critical case is in Rio Grande da Serra, in which $100 \%$ of its area is located within the BZ. By considering the sum of areas located in the SMSP and the BZ, it was observed that 25 municipalities have more than $30 \%$ of their areas within the study region, nine of which - Cubatão, Pedro de Toledo, Rio Grande da Serra, São Sebastião, Ubatuba, Mongaguá, Itanhaém, Bertioga, and Caraguatatuba — present values of over $90 \%$.

Table 1 shows the geographical territory of each municipality, as well as their areas inside the SMSP and its BZ. All the municipalities are located in the state of São Paulo with the exception of Parati which is located in the State of Rio de Janeiro.

\section{Demographic pressure}

Simões (2010) has studied the northern region of SMSP, and found numerous social conflicts over biodiversity conservation, which have been caused by the creation of a full protection conservation unit that disregarded the presence of residents in its territory. Among the reasons noted, the following could be emphasized: (1) strengthening expectations about compensation or expropriation of occupied areas; (2) aggravation of social exclusion situations, especially in areas occupied by fishermen and family farmers; (3) situations of conflict involving residents and environmental agents; and (4) aggravation of risks to biodiversity caused by real estate speculation. These conflicts jeopardize the governability of CUs, thus justifying the non-compliance of particular responsibilities by several governmental instances, as well discrediting public opinion of people who inhabit the surrounding areas.

Raimundo (2015), by focusing on the northern region of the SMSP, analyzed the environmental and cultural impacts from the perspective of local residents and the process of real estate speculation resulting from a progressive construction of other leisure homes by urban landowners. It was observed that the construction of second homes is limited to old local villages, and does not represent improvement in the natural environment. On the other hand, this author suggests that this situation ensures social and economic use of the area by providing work and income to local communities while not interfering with surrounding ecosystems at the same time. Thus, concluding that conflicts among locals, second-home owners, and environmental agents of the park have not yet come to a permanent solution, and that the progress of negotiations depends on local governance capacity. Similarly, Mannigel (2008) developed a theoretical framework to characterize the different levels of participation of four different community groups in the management of three protected areas considering that community participation is increasingly valued.

By analyzing the urban expansion of São Vicente, $\mathrm{SP}$, in the southern region of the SMSP which has a large portion of its territory inside the SMSP and BZ, Mello et al. (2013) have found a non-sustainable development related to the expansion of economic activities in the region, not considering the environmental and socio-cultural implications. The settlements, mostly developed along the highways, were mainly responsible for the suppression of areas of mangrove and restinga. A drastic replacement of the existing natural landscape by anthropic landscape, with irregular occupations and no adequate urban infrastructure, was noted and that the remainder of the natural vegetation, largely protected by law, increasingly suffers from the pressure from economic sectors finding new areas to expand their activities. 
Table 1 Areas of municipalities in the study region (source: Starzynski 2014)

\begin{tabular}{|c|c|c|c|c|c|c|}
\hline \multicolumn{2}{|l|}{ Municipality } & \multicolumn{2}{|c|}{ Serra do Mar State Park } & \multicolumn{2}{|l|}{ Buffer zone } & \multirow{2}{*}{$\begin{array}{l}\text { Total } \\
\% \text { SMSP + BZ }\end{array}$} \\
\hline Name & Area $\left(\mathrm{km}^{2}\right)$ & Area $\left(\mathrm{km}^{2}\right)$ & $\%$ of municipal area & Area $\left(\mathrm{km}^{2}\right)$ & $\%$ of municipal area & \\
\hline Bertioga & 490.1 & 232.5 & 47.4 & 225.4 & 46.0 & 93.4 \\
\hline Biritiba Mirim & 317.4 & 58.8 & 18.5 & 173.1 & 54.5 & 73.0 \\
\hline Caraguatatuba & 485.1 & 324.5 & 66.9 & 126.9 & 26.2 & 93.0 \\
\hline Cubatão & 142.9 & 62.2 & 43.5 & 80.8 & 56.6 & 100.0 \\
\hline Cunha & 1407.3 & 99.4 & 7.1 & 191.6 & 13.6 & 20.7 \\
\hline Embu-Guaçu & 155.6 & 0.0 & 0.0 & 63.9 & 41.0 & 41.0 \\
\hline Guarujá & 143.5 & 0.0 & 0.0 & 56.4 & 39.3 & 39.3 \\
\hline Itanhaém & 601.7 & 232.1 & 38.6 & 338.7 & 56.3 & 94.9 \\
\hline Itariri & 273.7 & 0.0 & 0.0 & 232.4 & 84.9 & 84.9 \\
\hline Juquitiba & 522.2 & 29.1 & 5.6 & 294.2 & 56.3 & 61.9 \\
\hline Miracatu & 1001.5 & 0.0 & 0.0 & 399.3 & 39.9 & 39.9 \\
\hline Mogi das Cruzes & 712.7 & 1.9 & 0.3 & 206.6 & 29.0 & 29.3 \\
\hline Mongaguá & 142.0 & 38.4 & 27.1 & 98.3 & 69.2 & 96.3 \\
\hline Natividade da Serra & 833.4 & 83.0 & 10.0 & 284.9 & 34.2 & 44.2 \\
\hline Paraibuna & 809.6 & 60.7 & 7.5 & 268.9 & 33.2 & 40.7 \\
\hline Parati (Rio de Janeiro state) & 925.1 & 0.0 & 0.0 & 183.7 & 19.9 & 19.9 \\
\hline Pedro de Toledo & 670.4 & 435.2 & 64.9 & 235.6 & 35.1 & 100.0 \\
\hline Peruíbe & 324.1 & 60.2 & 18.6 & 117.1 & 36.1 & 54.7 \\
\hline Praia Grande & 147.1 & 46.0 & 31.3 & 32.5 & 22.1 & 53.3 \\
\hline Ribeirão Pires & 99.1 & 0.0 & 0.0 & 39.8 & 40.2 & 40.2 \\
\hline Rio Grande da Serra & 36.3 & 0.0 & 0.0 & 36.3 & 100.0 & 100.0 \\
\hline Salesópolis & 425.0 & 76.7 & 18.1 & 216.9 & 51.0 & 69.1 \\
\hline Santo André & 175.8 & 2.3 & 1.3 & 90.0 & 51.2 & 52.5 \\
\hline Santos & 280.7 & 116.5 & 41.5 & 114.0 & 40.6 & 82.1 \\
\hline São Bernardo do Campo & 409.5 & 109.5 & 26.7 & 181.2 & 44.3 & 71.0 \\
\hline São Lourenço da Serra & 186.3 & 0.0 & 0.0 & 18.5 & 9.9 & 9.9 \\
\hline São Luiz do Paraitinga & 617.3 & 74.7 & 12.1 & 92.9 & 15.0 & 27.1 \\
\hline São Paulo & 1521.1 & 45.9 & 3.0 & 209.7 & 13.8 & 16.8 \\
\hline São Sebastião & 399.7 & 269.4 & 67.4 & 115.8 & 29.0 & 96.4 \\
\hline São Vicente & 147.9 & 66.4 & 44.9 & 49.6 & 33.5 & 78.4 \\
\hline Suzano & 206.2 & 0.0 & 0.0 & 20.0 & 9.7 & 9.7 \\
\hline Ubatuba & 723.8 & 512.3 & 70.8 & 185.1 & 25.6 & 96.4 \\
\hline Total & & 3037.8 & & 4980.0 & & \\
\hline
\end{tabular}

The pressure exerted by disorderly processes of urban sprawl in and around CUs is, therefore, a cause for concern requiring efforts to mitigate its effects on the environment to be protected. The first step is to undertake an analysis that shows how serious the problem is and defines priority regions for interventions.

\section{Method}

The present work has been undertaken using both alphanumeric data from a spreadsheet and topographic and thematic maps generated in shapefile and geodatabase formats. Spatial analyses were performed by using the ArcGIS®/ESRI, version 10.1. Boundaries data of SMSP 
and its BZ were obtained from the management plan (São Paulo 2006a, b) which was extracted from the website of the Foundation for the Conservation and Forestry Production of the State of São Paulo (http://fflorestal.sp.gov. br/planos-de-manejo/planos-de-manejo-planosconcluidos). All these data are on shapefile format which is suitable for being used in geoprocessing software. Demographic Census data were obtained from the Brazilian Institute of Geography and Statistics (IBGE Instituto Brasileiro de Geografia e Estatística) for the year 2010, as well as geographic boundaries and municipal areas (IBGE 2010).

The SMSP and BZ areas of each municipality were calculated in a geoprocessing environment by clipping the municipal boundaries. In addition, the percentages of municipal areas in the SMSP and its BZ were calculated, which considered the municipal geographic areas provided by IBGE as reference. Figure 1 contains a flowchart showing the procedures adopted to available information integrating alphanumeric and cartographic data.

The analysis of 2010 Census data has been carried out for each census sector, which was defined by IBGE as the smallest territorial unit formed by a continuous area. This territorial division makes it possible to conduct analysis and to manage cadastral data at an appropriate scale. Consequently, information was collected for all sectors located in the study area. In order to identify the census sectors that are part of the study area, census digital network data was combined using a GIS considering the SMSP boundary and its BZ. Demographic data was obtained through a spreadsheet published by IBGE, entitled Domicilio Spreadsheet 02 UF.xls. For each census sector, the number of residents in permanent private households has been used, which made it possible to calculate its total population, as well as determine population density in the study area.

As mentioned before, data input for analysis occurred in both spreadsheet and shapefile formats. In a geoprocessing environment, SMSP and its BZ boundaries, as well as municipal boundaries and geographical data of IBGE census, were added in ArcMap. In the spreadsheet environment, the IBGE population quantitative data for the 2010 Census were inserted. The research data were transferred from one environment to another in order to perform a spatial analysis. Once census network quantitative data was transferred into a geoprocessing environment, the reverse procedure was performed; the codes identifying each of the regional sectors were transferred to a spreadsheet environment in order to calculate resident population inside the SMSP and its BZ for each municipality. As a final stage, the results were sent back to a geoprocessing environment for calculating population density and the elaboration of tables and final maps.

\section{Results}

By considering the SMSP and its BZ, the study has evaluated 1560 census sectors, where 737,928 residents lived in 2010. Inside the SMSP, 127 census sectors were identified, in which lived 24,437 inhabitants, and the denser regions were located in the municipalities of Cubatão (12,992 inhabitants), Ubatuba (8637), Peruíbe (672), and Pedro de Toledo (545); $93.49 \%$ of the inhabitants of the interior of the park resides in these four municipalities. It was observed that population density varied from 0 to 30,962 inhab. $\mathrm{km}^{-2}$, and there were no residents in $70.02 \%$ of the park area, which is a necessary condition for the full protection conservation as specified by SNUC, since its essential aim is to environmental protection by admitting only an indirect use of natural resources. Private properties within its boundaries must be expropriated and residents should be compensated and relocated outside the CU. The highest population densities within the SMSP were found in the municipalities of Ubatuba, where the highest value was 2760 inhab. $\mathrm{km}^{-2}$ and Cubatão which had 13 sectors with densities ranging between 6091 and 10,000 inhab. $\mathrm{km}^{-2}$ and 4 sectors with demographic densities from 13,597 to 30,926 inhab. $\mathrm{km}^{-2}$.

In the BZ, 1432 census sectors were located, in which about 710,000 residents lived. Inhabitant distribution was characterized by denser regions, due to the fact that while $71 \%$ of these residents lived in $2.90 \%$ of the BZ, $28 \%$ of inhabitants lived in $97.00 \%$ of its area. Its population density ranged between zero and 74,436 inhab. $\mathrm{km}^{-2}$, given that the municipalities of Cubatão, São Vicente, Itanhaém, Guarujá, Bertioga, Caraguatatuba, São Sebastião, and Ubatuba are located in the coastal region while São Bernardo do Campo, Ribeirão Pires, and Rio Grande da Serra are located in the plateau region and represent those with the highest densities. Table 2 shows demographic densities both within the SMSP and its BZ, and the area percentage of these regions for each population density.

The population density distribution in SMSP and its BZ is presented in Figs. 2 and 3, for the southern and 


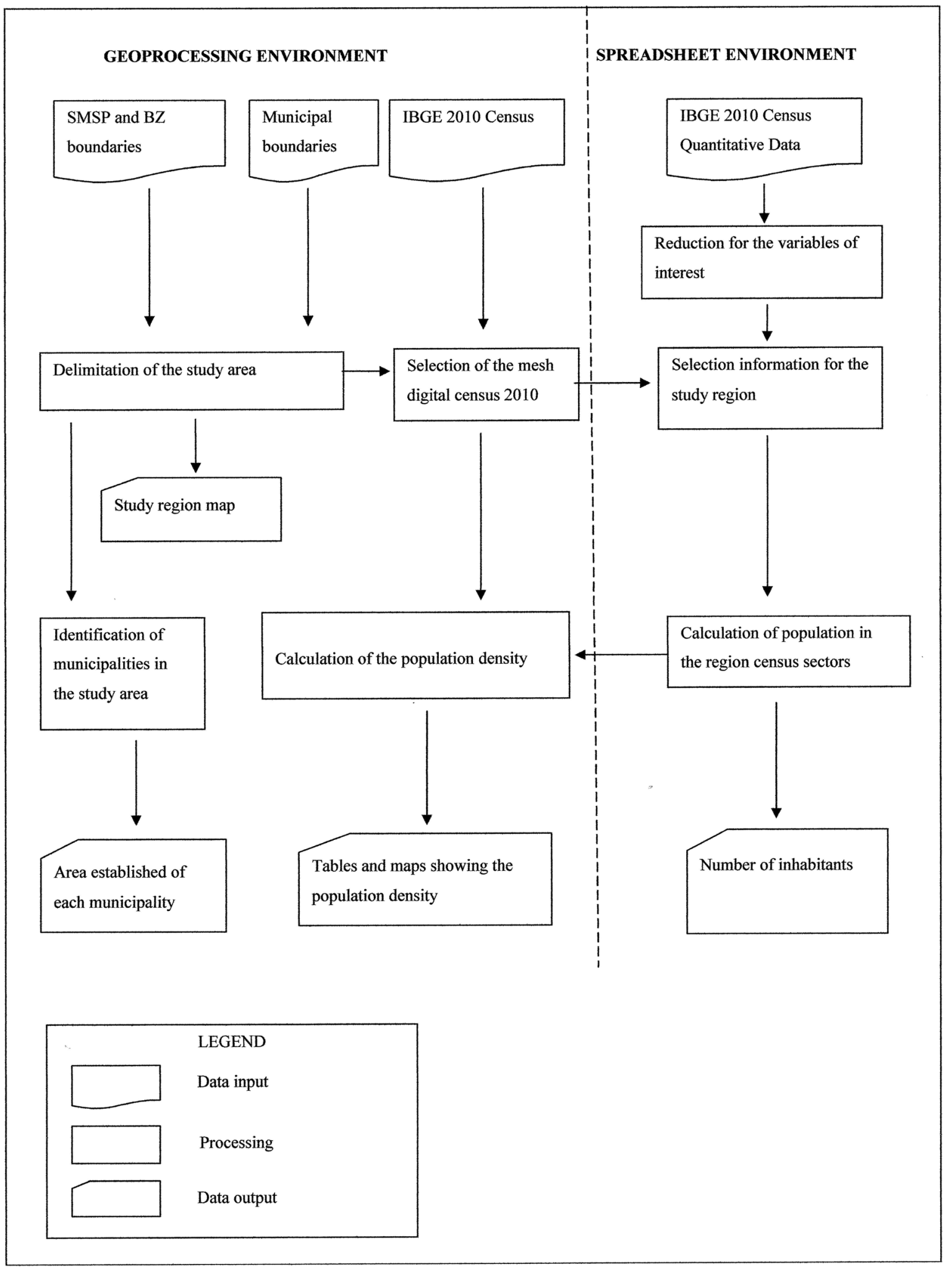

Fig. 1 Flowchart of methodological procedures 
Table 2 Population density within SMSP and its BZ

\begin{tabular}{lll}
\hline Population density (inhab.km $\left.{ }^{-2}\right)$ & SMSP area (\%) & BZ area (\%) \\
\hline 0 & 70.02 & 11.46 \\
$1-36$ & 28.98 & 67.55 \\
$37-216$ & 0.54 & 13.37 \\
$217-815$ & 0.27 & 4.71 \\
$816-2349$ & 0.09 & 1.83 \\
$2350-5842$ & 0.05 & 0.63 \\
$5843-12,665$ & 0.04 & 0.29 \\
$12,666-74,436$ & 0.01 & 0.16 \\
\hline
\end{tabular}

northern regions, respectively. This partitioning was performed in order to provide a better visualization and greater clarity in the presentation of information. In Fig. 2, it is possible to note that the greatest demographic pressure occurred in the coastal area, where the population density is very high on the BZ, particularly in the municipalities of Itanhaém and Mongaguá (Fig. 2(A)).

In the municipality of São Vicente, as well as in the municipalities of Pedro de Toledo and São Bernardo do Campo, the regions with the highest population densities were close to the CU boundaries. In the municipality of Cubatão (Fig. 2(B)), the BZ presented a high population density in its boundaries, as well as inside the $\mathrm{CU}$, while the municipalities of Ribeirão Pires, Rio Grande da Serra, and Santo André (Fig. 2(C)) had the largest population in the BZ. The municipality of Cubatão, near the border with Santo André, is the narrowest part of the SMSP, which is approximately $2 \mathrm{~km}$ wide which, together with high population density, makes it the most critical regarding preservation of biodiversity in the CU.

Figure 3 shows the population density in the northern region of SMSP and its BZ. In the same way, the highest demographic pressure occurred in the coastal area, where the BZ presented high demographic densities particularly in the municipalities of Caraguatatuba (Fig. 3(A)) and Ubatuba (Fig. 3(B)). Unlike in the plateau region, the demographic pressure on the $\mathrm{BZ}$ was significantly lower providing the $\mathrm{CU}$ with a buffer effect fulfilling its fundamental role.

It was observed that there is no agreement between the boundaries of sectors defined by IBGE and those for the SMSP and its BZ. In this context, a criterion was adopted for including or excluding sectors located in the study region's peripheral areas. If most of its area (over 50\%) were located inside the study region, the sector would be included; otherwise, it would be excluded. This approach may have led to minor errors in calculating resident population in the study area. In Figs. 2 and 3, the effect of this methodological decision can be seen on the maps showing population density, where regions without data are observed in the peripheral region of the BZ.

\section{Conclusion}

The results of this work may guide the process of implementing public policies and government actions for the regions of greatest demographic pressure inside the SMSP. The present study has revealed that, in 2010, there was a significant presence of residents living inside the SMPS, i.e., in approximately $30 \%$ of its area, and that there were significant human settlements particularly in the municipalities of Cubatão and Ubatuba. This fact is a direct consequence of the delayed process of creation of CUs in the country, which only evolved from the 1970s. In this process, several CUs were created in areas where there was already human occupation; however, effective measures were not taken to address the situation of the people that lived inside and surrounding of the conservation units. This has led to major territorial conflicts and competition for natural resources, making it very difficult the management of the protected areas.

The presence of these agglomerates constitutes a threat to the $\mathrm{CU}$, both because of the risk of preserving biodiversity posed by an illegal extraction of its natural resources and by the impact of managing these areas, which is characterized by urbanization impact such as service network expansion, infrastructure, construction of social facilities and housing, among others. The resulting loss of biodiversity and impacts on soil and water resources, as well as waste generation, compromise the resilience of these regions. This situation is incompatible with the proposals and objectives of the $\mathrm{CU}$, in accordance with the national legislation since its basic objective is the preservation of nature, permitting only the indirect use of natural resources. The individual properties within the $\mathrm{CU}$ should be expropriated, and the residents compensated and transferred out of the $\mathrm{CU}$.

The demographic distribution of the BZ was characterized by regions of great population density. In municipalities where there is strong anthropic pressure in $\mathrm{BZ}$, a detailed study is needed in order to understand the characteristics of this occupation as well as the causes of 


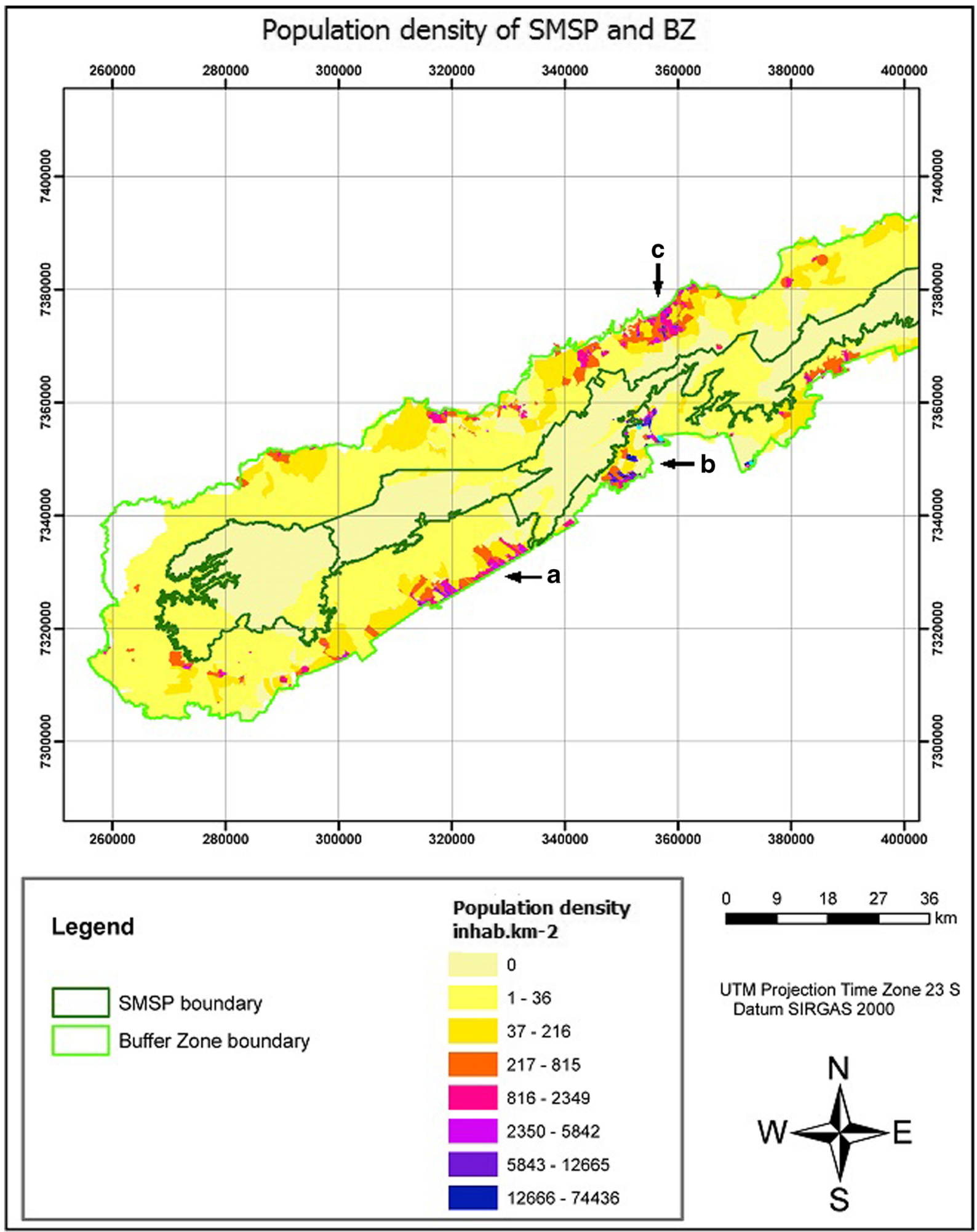

Fig. 2 Population density (inhab. $\mathrm{km}^{-2}$ ) in the southern region of SMSP and its BZ. (A) Itanhaém and Mongaguá; (B) Cubatão; and (C) Ribeirão Pires, Rio Grande da Serra, and Santo André 


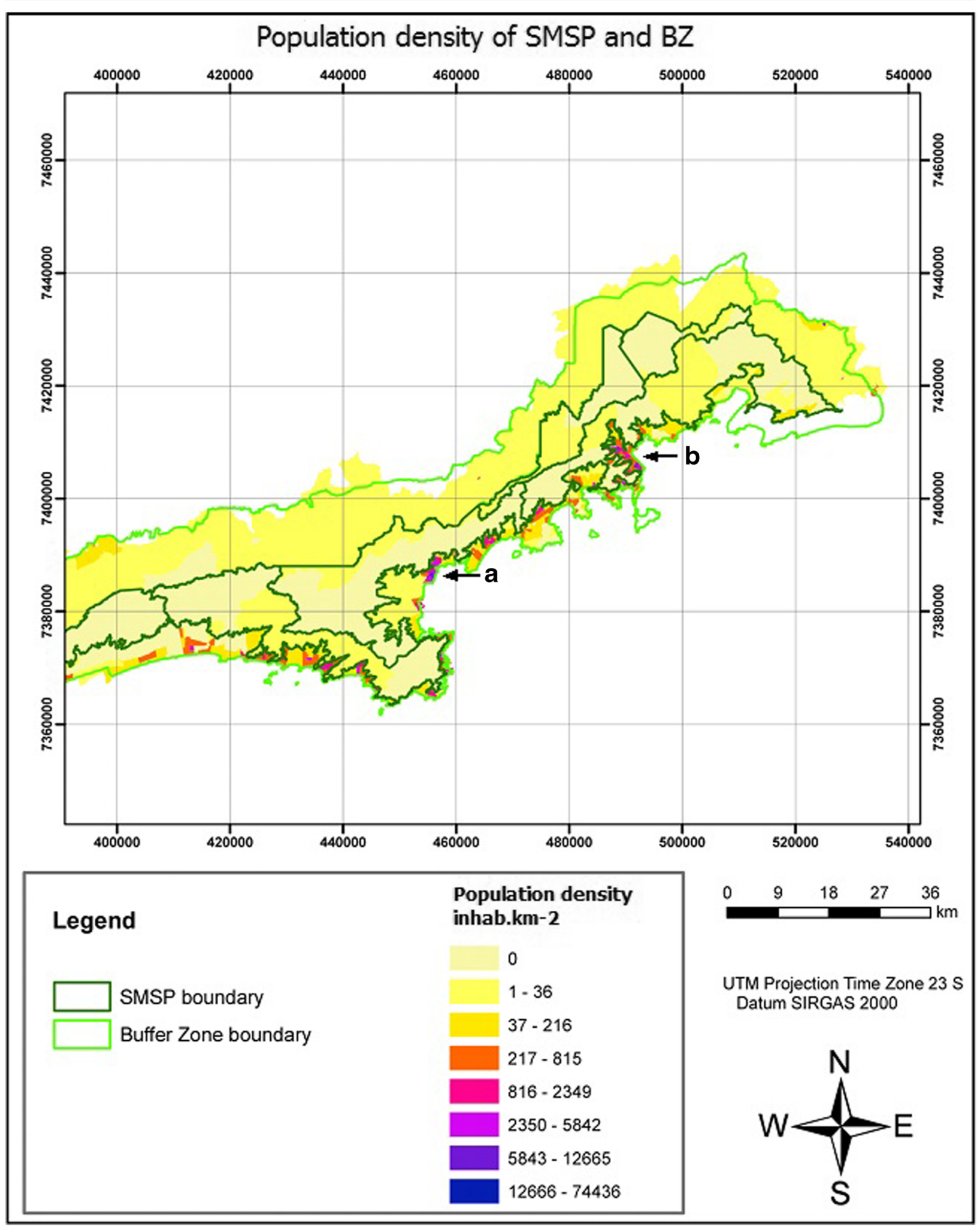

Fig. 3 Population density (inhab. $\mathrm{km}^{-2}$ ) in the northern region of SMSP and its BZ. (A) Caraguatatuba and (B) Ubatuba 
urban sprawl towards the CU. It is fundamental to investigate the effect of the municipal planning of urban expansion on the human occupations in the surrounding of the CU.

In certain areas, the high population density suggests a resizing of the $\mathrm{BZ}$ through quantitative and qualitative criteria based on ecological, social, and economic factors. As mentioned before, it is important to note that there was a lack of agreement between the boundaries of census sectors established by IBGE based on 2010 Demographic Census and the boundaries of the SMSP and its BZ obtained in this work. Therefore, it is suggested that, in the following census surveys, a delimitation of sectors should take into account the boundaries of legally established CUs in order to allow a more accurate analysis of resident population inside and around the protected areas.

\section{References}

Almeida, D., André, M., Scariot, E. C., Fushita, A. T., Dos Santos, J. E., \& Bogaert, J. (2018). Temporal change of Distance to Nature Index for anthropogenic influence monitoring in a protected area and its buffer zone. Ecological Indicators, 91.

Bamford, A. J., Ferrol-Schulte, D., \& Wathan, J. (2014). Human and wildlife usage of a protected area buffer zone in an area of high immigration. Oryx, 48(4), 504-513.

Bernard, E., Penna, L. A. O., \& Araújo, E. (2014). Downgrading, downsizing, Degazettement, and reclassification of protected areas in Brazil. Conservation Biology, 28(4), 939-950.

Brasil. Conselho Nacional do Meio Ambiente (1990). Resolução CONAMA $n^{\circ}$. 13. Dispõe sobre o licenciamento ambiental no entorno de Unidades de Conservação. Brasília, DF.

Brasil. Lei n. 9.985 (2000). Institui o Sistema Nacional de Unidades de Conservação da Natureza e dá outras providências. http://www.planalto.gov.br/ccivil_03 /leis/19985.htm. Accessed 4 July 2013.

Castro Júnior, E., Coutinho, B. H., \& Freitas, L. E. (2009). Gestão da biodiversidade e áreas protegidas. In A. J. T. Guerra \& M. C. N. Coelho (Eds.), Unidades de Conservação: abordagens e características geográficas. Rio de Janeiro: Bertrand Brasil.

Costa, N. M. C., Costa, V. C., Valim, C. B., Souza, A. C. C. C., \& Sales, A. C. G. (2011). Significado e importância da zona de amortecimento de unidades de conservação urbanas: o exemplo do entorno das áreas legalmente protegidas da cidade do rio de janeiro. Geo UERJ. http://www.epublicacoes.uerj.br/index.php/geouerj/article/view/1298. Accessed 10 Aug 2015.

De Marques, A. A. B., \& Peres, C. A. (2015). Pervasive legal threats to protected areas in Brazil. Oryx, 49(1), 25-29.

Freitas Lima, E. A. C., \& Ranieri, V. E. L. (2018). Land use planning around protected areas: case studies in four state parks in the Atlantic Forest region of southeastern Brazil. Land Use Policy, 71.

Geneletti, D., \& Duren, I. V. (2008). Protected area zoning for conservation and use: a combination of spatial multicriteria and multiobjective evaluation. Landscape and Urban Planning, 85(2), 97-110.

Harvey, C. A., Komar, O., Chazdon, R., Ferguson, B. G., Finegan, B., Griffith, D. M., Martínez-Ramos, M., Morales, H., Nigh, R., Soto-Pinto, L., Van Breugel, M., \& Wishnie, M. (2008). Integrating agricultural landscapes with biodiversity conservation in the Mesoamerican hotspot. Conservation Biology, 22(1), 8-15.

Hoffman, D. M., Fay, D., \& Joppa, L. (2011). Human migration to protected area edges in Africa and Latin America: questioning large-scale statistical analysis. Conservation and Society, 9(1), 1-7.

Instituto Brasileiro de Geografia e Estatística - IBGE (2010). Censo Demográfico. Características da População e dos Domicílios. (2011). ftp://geoftp.ibge.gov.br/malhas digitais/censo_2010/setores_censitarios/. ftp://ftp.ibge.gov. br/Censos/Censo_Demografico_2010/Resultados_do Universo/Agregados_por_Setores_Censitarios/. Accessed $\overline{4}$ July 2013.

Joppa, L. (2011-2012). Population change in and around protected areas. Journal of Ecological Anthropology, 15 (1).

Li, W., Wang, Z., \& Tang, H. (1999). Designing the buffer zone of a nature reserve: a case study in Yancheng Biosfere Reserve, China. Biological Conservation, 90(3), 159-165.

Lima, O., Melloni, R., \& Melloni, E. G. P. (2013). Antropização da zona de amortecimento da reserva biológica Serra dos Toledos (Itajubá-MG) e seu efeito na qualidade do solo. Cerne, 19(3), 373-381.

Mannigel, E. (2008). Integrating parks and people: how does participation work in protected area management? Society \& Natural Resources, 21(6), 498-511.

Mello, K., Toppa, R. H., Abessa, D. M. S., \& Castro, M. (2013). Dinâmica da expansão urbana na zona costeira brasileira: o caso do município de São Vicente, São Paulo, Brasil. Revista de Gestão Costeira Integrada, 13(4), 527-539.

Mmom, P. C., \& Mbee, D. M. (2013). Population pressure and forest resources depletion in Gele-Gele Forest Reserve of Edo state, Nigeria. International Journal of Physical and Human Geography, 1(3), 31-42.

Moraes, M. C. P., Mello, K., \& Toppa, R. H. (2015). Análise da paisagem de uma zona de amortecimento como subsídio para o planejamento e gestão de unidades de conservação. Revista Árvore, 39(1), 1-8.

Moraes, M. C. P., Mello, K., \& Toppa, R. H. (2017). Protected areas and agricultural expansion: biodiversity conservation versus economic growth in the Southeast of Brazil. Journal of Environmental Management, 188, 73-84.

Nora, E. L. D., Santos, J. E., Moreira, M. A., \& Santos, C. A. (2009). Caracterização ambiental dos usos e ocupação da terra em zonas de amortecimento de uma área natural legalmente protegida. Estudo de caso: Estação Ecológica de Itirapina. In: Simpósio Brasileiro de Sensoriamento Remoto, XIV. Anais, INPE.

Raimundo, S. (2015). Conflicts among second homes, protected areas and traditional communities in southeastern coast of Brazil. Ambiente \& Sociedade, 18(4). 
Ribeiro, M. C., Metzger, J. P., Martensen, A. C., Ponzini, F. J., \& Hirota, M. M. (2009). The Brazilian Atlantic Forest: how much is left, and how is the remaining forest distributed? Implications for conservation. Biological Conservation, 142, 1141-1153.

Sabatini, M. C., Verdiell, A., Iglesias, R. M. R., \& Vidal, M. A. (2007). Quantitative method for zoning of protected areas and its spatial ecological implications. Journal of Environmental Management, 83(2), 198-206.

São Paulo (Estado). (1977). Decreto $N^{\circ}$. 10.251. Cria o Parque Estadual da Serra do Mar e dá providências correlatas. http://governo-sp.jusbrasil.com.br/legislacao/211617 /decreto-10251-77. Accessed 4 July 2013.

São Paulo (Estado) (2014). Decreto $n^{\circ}$ 60.302. Institui o Sistema de Informação e Gestão de Áreas Protegidas e de Interesse Ambiental do Estado de São Paulo - SIGAP e dá providências correlatas. (2014). http://governo-sp.jusbrasil. com.br/legislacao/114664863/decreto-60302-14-sao-paulosp. Accessed 15 Apr 2014.

São Paulo (Estado). Secretaria do Meio Ambiente (2006a). Instituto Florestal. Plano de Manejo do Parque Estadual da Serra do Mar. http://fflorestal.sp.gov.br/planos-demanejo/planos-de-manejo-planos-concluidos/. Accessed 4 July 2013.

São Paulo (Estado). Secretaria do Meio Ambiente (2006b). Deliberação CONSEMA 34 Aprova o Plano de Manejo do Parque Estadual da Serra do Mar. http://fflorestal.sp. gov.br/files/2012/01/Del34 SerradoMar.pdf. Accessed 8 January 2014.

Schimandeiro, A., Kantelhardt, J., \& Neto, P. H. W. (2008). Characterization of major crop management in the buffer zone of Vila Velha State Park, state of Paraná, Brazil. Acta Scientiarum. Agronomy, 30(2), 225-230.

Scinachi, C. A., Takeda, G. A. C. G., Mucci, L. F., \& Pinter, A. (2017). Association of the occurrence of Brazilian spotted fever and Atlantic rain forest fragmentation in the São Paulo metropolitan region, Brazil. Acta Tropica, 166, 225-233.

Simões, E. (2010). O dilema das decisões sobre populações humanas em parques: jogo compartilhado entre técnicos e residentes no Núcleo Picinguaba. 357 f Tese (Doutorado). Ambiente \& Sociedade do Instituto de Filosofia e Ciências Humanas da Universidade Estadual de Campinas.

Starzynski, R. (2014). Avaliação quantitativa do uso dos recursos hídricos em unidade de conservação e entorno. Estudo de caso do Parque Estadual da Serra do Mar. 79 f. Dissertação (Mestrado). Universidade Estadual Paulista "Julio de Mesquita Filho".

UNESCO (1971). The Man and the Biosphere Programme-MaB. http://www.unesco.org/new/pt/brasilia/naturalsciences/environment/biodiversity/biodiversity/mabprogramme-in-brazil/\#c1076335. Accessed 10 Aug 2015.

Vitalli, P. L., Zakia, M. J. B., \& Durigan, G. (2009). Considerações sobre a legislação correlata à zona tampão de unidades de conservação no Brasil. Ambiente \& Sociedade, 12(1), 67-82.

Wittemyer, G., Elsen, P., Bean, W. T., Burton, A. C., \& Brashares, J. S. (2008). Accelerated human population growth at protected area edges. Science, 321(5885), 123-126.

Zhang, Z., Sherman, R., Yang, Z., Wu, R., Wang, W., Yine, M., Yang, G., \& Ou, X. (2013). Integrating a participatory process with a GIS-based multi-criteria decision analysis for protected area zoning in China. Journal for Nature Conservation, 21(4), 225-240. 